\title{
Extrahepaticus manifesztációk idült hepatitis C-vírus-fertőzöttekben
}

\author{
Hagymási Krisztina dr. - Egresi Anna dr. - Lengyel Gabriella dr. \\ Semmelweis Egyetem, Általános Orvostudományi Kar, II. Belgyógyászati Klinika, Budapest
}

\begin{abstract}
A hepatitis C-vírus-fertőzés egészségügyi jelentősége világszerte kiemelkedő, a világ lakosságának 3\%-a fertőzött. Idült hepatitis C-fertőzöttek körülbelül 50\%-ában alakul ki extrahepaticus betegség, amely a betegek kilátásait, mortalitását rontja. Kialakulásuk hátterében részben krioglobulinok képződése, immunmechanizmusok, valamint a vírus direkt hatásai állhatnak. A szerzők összefoglalják a hepatitis C-vírus-fertőzéssel összefüggő szervi érintettségeket, valamint a kezelés lehetőségeit. Közleményükkel a társszakmák figyelmét kívánják felhívni a fertőzés sokszínúségére, ezzel segítve a kórkép felismerését a hatékony direkt antivirális készítmények időszakában. Orv. Hetil., 2017, 158(16), 603-612.
\end{abstract}

Kulcsszavak: hepatitis C-vírus-fertőzés, extrahepaticus manifesztáció, cryoglobulinaemia, vasculitis, antivirális kezelés

\section{Extrahepatic manifestations in chronic hepatitis $\mathrm{C}$ infected patients}

\begin{abstract}
The importance of chronic hepatitis C infection is significant. 3\% of the World's population is infected. There is at least one extrahepatic manifestation in $50 \%$ of $\mathrm{HCV}$ patients, which makes the prognosis and mortality worse. The pathomechanisms included are cryoglobulin production, immunmechanisms, and direct viral effects. The authors summarize the main extrahepatic manifestations, as well as treatment possibilities. The aim is to draw attention to this colourful infection in order to improve the recognition in the era of the new effective direct antiviral agents.
\end{abstract}

Keywords: hepatitis C virus infection, extrahepatic manifestation, cryoglobulinemia, vasculitis, antiviral treatment

Hagymási, K., Egresi, A., Lengyel, G. [Extrahepatic manifestations in chronic hepatitis C infected patients]. Orv. Hetil., 2017, 158(16), 603-612.

Az Orvosi Hetilap alapításának 160. évében a Szerkesztőség felkérésére készített tanulmány.

(Beérkezett: 2017. február 23.; elfogadva: 2017. március 16.)

\begin{abstract}
Rövidítés
$\mathrm{CCP}=$ ciklikus citrunilált peptid; $\mathrm{HCAO}=($ hepatitis $\mathrm{C}$ associated osteosclerosis) hepatitis C-vel összefüggő osteosclerosis; $\mathrm{HCV}=$ hepatitis C-vírus; IL = interleukin; ITP = immunthrombocytopeniás purpura; LAC-diéta $=$ (low-antigen-content diet) alacsony antigéntartalmú diéta; MALT-lymphoma = (mucosa-associated lymphoid tissue) mucosaasszociált lymphoid szöveti lymphoma; $\mathrm{MGN}=$ membranosus glomerulonephritis; MGUS = (monoclonal gammopathy of undetermined significance) nem meghatározott jelentőségű monoklonális gammopathia; $\mathrm{MHC}=$ major hisztokompatibilitási komplex; MPGN = membranoproliferativ glomerulonephritis; NHL = non-Hodgkin-lymphoma; WHO = World Health Organization
\end{abstract}

A hepatitis C-vírus- (HCV-) fertőzés egészségügyi jelentősége világszerte kiemelkedő, a megbetegedési és a halálozási statisztikákban meghatározó [1]. A fertőzöttek számát 210 millióra becsülik, a WHO adatai alapján a világ lakosságának körülbelül 3\%-a fertózött. Évente 3-4 millió az új fertőzés, valamint 366000 a HCV okozta halálozás [2].

A HCV-fertőzés lehetséges következménye az idült májkárosodás, a cirrhosis és a hepatocellularis carcinoma kialakulása. A HCV a cirrhosisok $27 \%$-áért, a hepatocellularis carcinomák 25-31\%-áért felelős [2,3].

Heveny fertózések 60\%-ában alakul ki idült hepatitis, de a vírus direkt hatása, inváziója, replikációja révén, va- 
lamint immunmediált folyamatok következtében a fertőzés nemcsak a májat érintheti. A fertőzöttek legalább 40-50\%-ában alakul ki extrahepaticus megjelenés [4].

Először Pascual és mtsai írtak le extrahepaticus tüneteket HCV-fertőzöttekben két cryoglobulinaemiás eset kapcsán [5]. Később Zignego és munkacsoportja a HCVfertőzésben megjelenő extrahepaticus manifesztációkat osztályozta: $A=a z$ összefüggés egyértelmú, a patomechanizmus ismert; $\mathrm{B}=$ a prevalencia nagyobb a kontrollcsoporthoz viszonyítva; $\mathrm{C}=$ a szindróma megerósítésre, pontosításra vár HCV-fertőzéssel összefüggésben; $\mathrm{D}$ = eseti megfigyelések $[6,7]$.

$\mathrm{Az}$ extrahepaticus manifesztációk kialakulásának mechanizmusa nem teljesen ismert. A leggyakoribb extrahepaticus megjelenés a II., III. típusú cryoglobulinaemia következtében kialakuló szisztémás vasculitis bőr-, vese-, valamint ízületi érintettséggel. Az extrahepaticus tünetek másik csoportjának hátterében nem a cryoglobulinaemia áll, szerepe lehet a vírusfehérjék és a gazdaszervezet fehérjéi közötti mimikrinek, immunreakcióknak, valamint a vírus replikációjának, direkt hatásának az adott szervben, szövetben $[8,9]$, amely szövetek a vírus rezervoárjául is szolgálnak, s később a fertőzés perzisztálását, reaktivációját magyarázzák [6].

Az extrahepaticus manifesztációk a HCV-fertőzöttek megbetegedését, halálozását jelentősen befolyásolják, életminőségüket rontják [10]. Az extrahepaticus szervek érintettségének kezelése részben a vírusellenes kezelést, a B-sejt-depléciót jelenti az immunkomplexek, krioglobulinok képződésének megakadályozására, valamint a nem specifikus immunszuppresszív kezelést foglalja magában, amelynek célja a gyulladásos sejtek immunkomplexképzésének gátlása, valamint a cryoglobulinaemiás vasculitis kezelése $[11,12]$.

\section{Cryoglobulinaemia okozta extrahepaticus manifesztációk}

\section{Cryoglobulinaemia általában}

A cryoglobulinaemia olyan fehérje, antitest, amely alacsony hőmérsékleten $\left(<37^{\circ} \mathrm{C}\right)$ reverzíbilisen precipitálódik, kicsapódik és kristályt képez, amely $37^{\circ} \mathrm{C}$ felett oldódik.

Három csoportba sorolható. Az I. típusban, amely az esetek 10-15\%-át jelenti, monoklonális IgM jelenik meg. Általában a lymphoproliferativ betegségeket jellemzi (myeloma multiplex, Waldenström-féle macroglobulinaemia, krónikus lymphocytás leukaemia, non-Hodgkinlymphoma, nehézlánc-betegség) [13].

A II. típus a leggyakoribb, az esetek 50-60\%-a, poliklonális IgG és monoklonális IgM megjelenésével. Jellegzetes HCV-fertőzésre, de más idült gyulladásokban, autoimmun folyamatokban is megjelenhetnek (szisztémás lupus erythematodes, rheumatoid arthritis) $[8,13]$.

A III. típusú cryoglobulinaemia kevert IgM típusú poliklonális immunkomplexekkel. Autoimmun folyama- tokat, fertőzéseket, szövetszéteséssel járó kórképeket jelezhet [13].

HCV-fertőzésben a II-es típusú cryoglobulinaemia a leggyakoribb. A kevert cryoglobulinaemiás betegek 70100\%-a anti-HCV-pozitív [14, 15]. Cryoglobulinok a HCV-fertőzöttek 40-60\%-ában mutathatók ki [8], a betegek 10-15\%-ában alakul ki szisztémás, a kis artériákat és vénákat érintő vasculitis $[8,16,17]$.

Az idült HCV-fertőzés elhúzódó lymphocytastimulációt eredményez, amely a B-sejtek klonális expanziójához és IgM immunglobulin képződéséhez vezet. A HCV-fertőzés következtében termelődő krioglobulinok, főleg az IgG-típusúak, a HCV-core és az NS3, NS4 epitopok ellen specifikusak. A krioprecipitálódó immunkomplexek a kiserek falában lerakódnak, Clq fehérjéhez kötődve a komplementrendszert aktiválják, gyulladásos reakciót hozva létre, amelynek endothelsérülés és cryoglobulinaemiás vasculitis a következménye $[8,17]$.

A Meltzer-triász (purpura, arthralgia, myalgia) a leggyakoribb tünete, a glomerulonephritis, a perifériás neuropathia, a lymphoproliferativ betegségek és a bőrfekély a legsúlyosabb megjelenési formák. B-sejt-lymphoproliferativ betegség 5-10\%-ban alakul ki [14].

A szimptómás betegek több mint $50 \%$-ában a klinikai lefolyás jóindulatú, a kórjóslat jó. A kockázati tényezők nem pontosan ismertek: a női nem (nő/férfi arány 2:1), az életkor, más autoimmun betegségek jelenléte, hoszszabb betegségfennállás, nagyobb krioglobulinszint rosszabb kórjóslatot jelentenek [18].

\section{Börérintettség}

Cryoglobulinaemiában cutan vasculitis csaknem mindig (95\%) jelen van. Fóleg az alsó végtagokon, leggyakrabban purpurák, illetve erythematosus papulák jelenhetnek meg. A tapintható purpurák szövettanilag leukocytoclasticus vasculitisnek felelhetnek meg. Ulceratio ritka, a cryoglobulinaemiás esetek 10-25\%-a [19]. A börelváltozások 40\%-ában mutatták ki a vírust [6].

\section{Veseérintettség}

Az immunkomplexek lerakódása a glomerularis kapillárisokban és a mesangiumban hozza létre a I. típusú membranoproliferativ glomerulonephritist (MPGN), amely a leggyakoribb HCV-asszociált veseérintettség $[12,13$, $20]$.

Az MPGN előfordulása gyakoribb cryoglobulinaemiás HCV-fertőzöttekben. A cryoglobulinaemia-asszociált MPGN-ek 80\%-ában, a nem cryoglobulinaemiához köthető MPGN-ek 25\%-ában mutatható ki a HCV [21].

Gyakran tünetmentes, de mikroszkópos haematuria, proteinuria, hypertonia, nephritis (30\%) és nephrosisszindróma $(25 \%)$ klinikai képében is megjelenhet, heveny veseelégtelenség, oliguria az esetek 5\%-ában alakul ki. A proteinuriás, csökkent vesemúködésű, cryoglobulinaemiás betegeknél vesebiopszia elvégzése javasolt. Kór- 
jóslata jó, lassú progresszió jellemzi az esetek 30\%-át, 20\%-ban a nephritisszindróma visszatér, a kevert típusú cryoglobulinaemia okozta membranoproliferativ glomerulonephritis 10\%-ban progrediál dialízist igénylő idült veseelégtelenségbe [6].

\section{Perifériás neuropathia}

Az idült HCV-fertőzés idegrendszeri tünetei hátterében gyakran a kevert cryoglobulinaemia, kisérvasculitis áll, bár a vírus jelenlétét kimutatták HCV-s beteg izom- és idegszövetében cryoglobulinaemia nélkül is [22]. Felmerült vitaminhiány és a társuló anyagcserezavarok (diabetes mellitus) kóroki szerepe is [13].

A cryoglobulinaemiához kapcsolódó perifériás neuropathia (7-90\%), mononeuropathia, multiplex mononeuropathia vagy polyneuropathia képében is jelentkezhet. Általában az érzőrendszer érintett (fájdalom, égés, erőtlenség érzete). A tünetek a cryoglobulinaemia súlyosságával korrelálnak, a végtagokat érinti $[6,8,23]$.

A cerebralis vasculitis: ischaemiás stroke, lacunaris szindróma, kognitív károsodás, encephalopathia ritkább megnyilvánulások [24].

\section{Musculoskeletalis érintettségek}

Aszimptomatikus ízületi érintettség és arthralgia gyakori idült HCV-fertőzésben. Váz- és izomrendszeri tünetek HCV-fertőzöttek 10-30\%-ában jelennek meg arthralgia, myalgia képében. A valódi arthritis a betegek $4 \%$-át érinti. Klinikailag két formája különböztethető meg. Az intermittáló mono-oligoarthritis leggyakrabban a nagyízületeket (térd, boka) érinti [25].

A gyakoribb, szimmetrikus polyarthritis-rheumatoidszerü arthritis (SP) enyhébb, nem erosiv jellegü, nem deformáló, a subcutan csomók hiányoznak, a betegek általában anti-CCP- (ciklikus citrunilált peptid) negatívak (anti-CCP-pozitivitás: $4-11 \%$ vs. rheumatoid arthritisben szenvedő betegek 75-83\%) [8, 25]. A HCV-fertőzöttek 70-80\%-a reumafaktor-pozitív, szintje nem korrelál az ízületi folyamattal [26].

Nemcsak cryoglobulinaemiához kapcsoltan, hanem az immunkomplexek synovialis lerakódása következtében is kialakulhat ízületi érintettség vírusfertőzöttekben, patomechanizmusában szerepet játszhat a HCV inváziója a synovialis sejtekbe $[8,26]$.

\section{Lymphoproliferativ betegségek}

Idült HCV-fertőzöttekben gyakoribbak a lymphoproliferativ betegségek. A non-Hodgkin-lymphoma kockázata 20-30\%-kal nagyobb: follicularis lymphoma, krónikus lymphocytás leukaemia, kis lymphocytás lymphoma, diffúz nagy B-sejtes lymphoma, margináliszóna-lymphoma alakulhat ki. B-sejt-lymphomások 35\%-a HCV-RNS-pozitív. Non-Hodgkin-lymphomások és cryoglobulinaemi- ás betegek 90\%-a HCV-RNS-pozitív. HCV-fertőzéssel összefüggésben kialakult non-Hodgkin-lymphoma 65\%-a extranodalis érintettségű (nyálmirigyek, máj) vs. 19\% nem HCV-kapcsolt NHL-ek [6]. A HCV-RNS-t MALT(mucosa-associated lymphoid tissue) lymphomás egyének gyomornyálkahártyájában is izolálták, amely a HCV patogenezisben betöltött szerepét veti fel [6]. Nem egyértelmû jelentőséggel bíró monoklonális gammopathiákkal (monoclonal gammopathy of undetermined significance - MGUS) (általában IgM/kappa) is összefüggésbe hozták a vírusfertőzést. MGUS a HCV-s betegek 11\%-ában van jelen cryoglobulinaemia nélkül. A betegeket multiplex myeloma irányában követni kell [6].

A hosszan fennálló HCV-fertőzés idült antigén-stimulációt, a B-sejtek klonális expanzióját hozza létre, amely más genetikai és környezeti tényezőkkel együtt onkogén-aktiváción keresztül lymphomaképződést indít el [6]. A fertőzött sejtekben kimutatható t(18;14)-transzlokáció a bcl 2 onkogén overexpressziójával, másodlagos mutációkkal szintén szerepet játszhat a lymphomaképződés folyamatában. A folyamatban szerepet játszhat a HCV lymphotropismusa, inváziója a B-sejtekbe, amely szintén lymphocytaproliferációt eredményez [6].

\section{Nem a cryoglobulinaemiával összefüggő extrahepaticus manifesztációk}

\section{Veseérintettség}

Idült HCV-fertőzöttek esélye 40\%-kal nagyobb a végstádiumú vesebetegségre az átlaglakossággal szemben. A HCV-pozitív egyénekben $40 \%$-kal nagyobb a vesemúködési zavar (kreatininszint $\geq 1,5 \mathrm{mg} / \mathrm{dl}$ ) szeronegatív egyénekhez viszonyítva [27].

Membranosus nephropathia (MGN), fokális szegmentális glomerulonephritis, postinfectiosus glomerulonephritis, fibrillaris glomerulonephritis, IgA-nephropathia (Berger-betegség), renalis thromboticus microangiopathia és interstitialis nephritis a leggyakoribb formák $[12,13,20]$.

A kórjóslata rossz a fertőzések és a társuló szív-ér rendszeri szövődmények miatt. HCV-fertőzöttek szűrése javasolt évente microalbuminuria, mikroszkópos haematuria, reumafaktor, cryoglobulinaemia, komplementfaktorok és hypertonia irányában. Az MPGN- vagy az MGN-betegeket HCV-fertőzés irányában szűrni kell [12].

\section{Immunthrombocytopeniás purpura}

A thrombocytopenia gyakori laboratóriumi eltérés HCV-fertőzöttekben, részben a splenomegaliahypersplenia szindróma, részben az antivirális kezelések mellékhatásaként. Enyhe thrombocytopenia (<150 000/ ul) a HCV-fertőzöttek 4l-50\%-ában van jelen. Immunmechanizmussal jön létre, a HCV-ellenes antitest kötő- 
dése a vérlemezkemembránhoz fagocitózist eredményez. Felszíni glikoprotein- (GP IIb/IIIa, Ia, Ib) ellenes antitesteket is kimutattak immunthrombocytopeniás purpurás HCV-fertőzöttekben [28].

A HCV-fertőzött immunthrombocytopeniás betegek idősebbek, a nemek eloszlása egyenlő, a thrombocytaszámuk magasabb (vs. idiopathiás ITP) $[8,28]$.

\section{Inzulinrezisztencia, diabetes mellitus}

HCV-fertőzöttekben gyakoribb az inzulinrezisztencia az átlaglakossághoz viszonyítva. Idült C-vírus hepatitisben szenvedő betegekben körülbelül 50\%-ban (40-88\%) mutatható ki a máj változó mértékú elzsírosodása, amely mintegy 2,5-szerese a más kórokú májbetegségben észleltnek (hepatitis B: $26 \%$, autoimmun májbetegség: 17\%) $[29,30]$.

A 2-es típusú diabetes mellitus előfordulása $28 \%$ Cheng és mtsai vizsgálatában [31].

A HCV okozta májzsírosodás esetében két csoport különíthetô el: a virális és a metabolikus steatosis. Metabolikus steatosis az $\mathrm{lb}$ genotípussal fertőzöttekben mutatható ki. A betegekben a metabolikus szindróma valamelyik alkotója - az elhízás, a hyperlipidaemia, a hypertonia és az inzulinrezisztencia - önállóan vagy egymással kombinálva, mindig kimutatható. Metabolikus elzsírosodás eseten a vírus közvetlen módon, a metabolikus X-szindrómával összefüggő utakon hozhat létre steatosist. A zsírmáj a sikeres antivirális terápia ellenére is megmaradhat [29].

Virális elzsírosodás a 3a genotípussal fertôzötteknél van jelen. Az elzsírosodás a vírus közvetlen sejtkárosító hatásának következménye, nem igazolható más, inzulinrezisztenciával összefüggő, elzsírosodást okozó tényező a háttérben. Az elzsírosodás mértéke összhangban van a vírusszinttel. Sikeres antivirális kezelést követôen az elzsírosodás csökken vagy megszúnik. Gyakran a két csoport nem különíthetô el [29].

$\mathrm{Az}$ inzulinrezisztenciát és a glükózintoleranciát a HCV-core fehérje az inzulinreceptor-szubsztrát fehérje 1,2 (IRS 1,2) expresszióját csökkentő hatása és a pancreas-béta-sejt-diszfunkció magyarázza [32].

$\mathrm{Az}$ inzulinrezisztencia és a hyperinsulinaemia az inzulinszerú növekedési faktor 1 és a transzformáló növekedési faktor- $\beta$ termelését, valamint az angiotenzin II receptor expresszióját fokozza a vese mesangialis sejtekben, felerősítve az angiotenzin II káros hatását. A növekedett endothelin-1-szint és a szabad gyökös reakciók szerepe sem elhanyagolható az inzulinrezisztencia okozta vesekárosodás kialakulásában. A HCV a diabeteses nephropathia progresszióját segítheti, a vesefunkció-romlás gyorsabb HCV-pozitív diabeteses nephropathiásokban a HCV-negatív egyénekhez hasonlítva [12].

HCV-fertőzött cukorbetegekben fokozott a cirrhosis és a hepatocellularis carcinoma kialakulásának kockázata $[33,34]$.

\section{Autoimmun betegségek}

\section{Sjögren-szindróma}

Sjögren-szindróma a HCV-fertőzöttek 26-53\%-ában alakul ki. A Sjögren-szindrómás betegek 6\%-a HCV-pozitív (vs. 2\% átlagpopuláció) [35]. Részben a HCV-antigének és a nyálmirigyszövet-antigének közötti keresztreaktivitás magyarázza, de a vírus direkt hatása is felmerült. Jellemző, hogy az SS-A és anti-SS-B előfordulása ritkább, viszont a hypocomplementaemia, a krioglobulinok, valamint az antinukleáris antitestek elófordulása gyakoribb, szövettanilag a gyulladás enyhébb, a betegek idősebbek (vs. klasszikus Sjögren-szindróma) $[8,20$, 36]. Általában arthritis vagy más szisztémás manifesztáció is jelen van [8].

\section{Egyéb autoimmun betegségek}

HCV-fertőzöttekben számos, nem egyértelmú klinikai relevanciával bíró, nem szervspecifikus, illetve szervspecifikus antitestek jelenhetnek meg [37]: reumafaktor $(60 \%)$, antinukleáris antitest $(40 \%)$, pajzsmirigyellenes antitestek (35\%), antikardiolipin (15\%) és antisimaizomellenes antitest (7\%) [20]. A HCV-fertőzöttek felének van legalább egy immunológiai eltérése [18], klinikai jelentőségük csekély [20].

A szisztémás lupus erythematosus az egyik leggyakoribb autoimmun betegség HCV-fertőzöttekben, az antidsDNS szintje kisebb és a pillangóerythema elófordulása ritkább, a cutan vasculitis gyakoribb [8].

A CREST-szindróma még ritkább megjelenés: calcinosis, Raynaud-szindróma, esophagealis dysmotilitás, sclerodactylia, teleangiectasia $[8,37]$.

\section{Pajzsmirigybetegségek}

\section{Hashimoto-thyreoiditis}

Egyértelmű a fertőzések szerepe az autoimmun thyreoiditisek kialakulásában. A lehetséges fertőző ágensek közül a HCV összefüggése az autoimmun pajzsmirigybetegségekkel a legerősebb [35].

HCV-fertőzött betegek 13\%-ában alakul ki hypothyreosis, a betegek $25 \%$-ában pajzsmirigyellenes antitestek mutathatók ki. Antivirális kezelés során pajzsmirigybetegség (Graves-betegség, Hashimoto-thyreoiditis) relatív kockázata nagyobb (RR 4,4). A kezelés következtében kialakuló hypothyreosis 50\%-ban reverzíbilis, pajzsmirigyantitest- (antiperoxidáz-antitest) pozitivitás a kezelés kezdetekor kockázati tényezôt jelent kialakulására, főleg idősebb nókben [6]. Beszámoltak a papillaris carcinoma gyakoribb előfordulásáról is HCV-fertőzöttekben [38].

HCV-fertőzöttekben a kezeléstől függetlenül is kimutathatóak autoantitestek, amelyek hátterében számos autoimmun mechanizmus feltételezhető: saját antigén ex- 
pressziójának megváltozása, lokális gyulladás indukciója citokinfelszabadulással, amely az autoreaktív T-sejtek aktivációját eredményezi, a vírusantigének és a pajzsmirigyantigének között fennálló molekuláris mimikri, heat shock fehérje indukciója, az MHC II molekulák aberráns expressziója a pajzsmirigysejteken. Kimutatták, hogy a HCV E2 fehérje kölcsönhatása a CD81-expreszszáló thyroid sejtekkel fokozott IL-8-produkciót hoz létre, amelynek a chemotaxis, valamint az angiogenesis fokozása a következménye [8, 35].

HCV-RNS-t kimutattak pajzsmirigysejtekben, ezért feltételezhető, hogy a pajzsmirigybetegségek kialakulásában szerepet játszhat a HCV direkt hatása, replikációja a pajzsmirigysejtekben. A pajzsmirigysejtek a HCV extrahepaticus replikációjának rezervoárjai lehetnek, s szerepet játszhatnak nemcsak a pajzsmirigy-autoimmunitás kialakulásában, hanem a fertőzés fenntartásában is $[8$, $35,39]$.

HCV-s betegek szűrését javasolják pajzsmirigy-múködési zavar irányában $[13,20]$.

\section{Szív-ér rendszeri betegségek}

HCV-fertőzöttekben nagyobb az atherosclerosis, s így a coronariabetegség, valamint a cerebrovascularis történések kockázata [13, 40]. A korai és az előrehaladott carotisatherosclerosis kockázata négyszer nagyobb HCV-fertőzöttekben a vírusmentes egyénekhez viszonyítva [20]. Egy áttekintő tanulmány szerint az összefüggés további megerősítésre vár [41].

Bár idült C-vírus-fertőzésben a szív-ér rendszeri betegségek tekintetében kedvezőbb a kockázati tényezők előfordulása: kevésbé jellemző a hypertonia, kisebb az összkoleszterin-, LDL-koleszterin- és trigliceridszint [13], a nagyobb cardiovascularis kockázat hátterében a szabad gyökök, a gyulladásos citokinek (TNF- $\alpha$, IL-6) felszabadulása, az inzulinrezisztencia, az endothelellenes antitestek megjelenése, valamint az intracelluláris adhaesiós molekulák fokozott expressziója állhat [40].

A vírus in situ replikációját is kimutatták a carotisplakkokban, amelynek proatherogen hatása lehet [42].

\section{Bőrtünetek}

A betegek 20\%-a számol be pruritusról, amelynek hátterében az epesavak, valamint az opioidok emelkedett szintje is állhat [11].

A lichen planus gyakoribb előfordulásának (10-23\%) pontos magyarázata, mechanizmusa nem ismert. A vírust lichen planusos bőrlaesiókból kimutatták, feltételezhető, hogy immunválaszt indukál [8]. A HCV és a desmoglein-3 közötti antigén mimikri szerepe is felmerült [20]. A praecancerosisnak tekinthető oral lichen planusos betegek 27\%-a HCV-pozitív [6, 13 ].

A psoriaticus plakkok megjelenése, az erythema nodosum és az erythema multiforme kevésbé gyakori manifesztációk [8].
A porphyria cutanea tarda a leggyakoribb porphyriaforma, amely a májat és a bört érinti. Leggyakrabban HCV-fertőzés következménye, de más idült májbetegségben (haemochromatosis, alkoholos májbetegség) is megjelenhet [8]. Porphyriás betegek 40-50\%-a HCVpozitív. A vírus okozta porphyria pontos mechanizmusa nem ismert, feltételezik, hogy az idült HCV-fertőzés a májsejtekben a glutationszint csökkentésével károsítja a porfirin-anyagcserét. A redukált glutation hiánya következtében az oxidált uroporfirinek felhalmozódnak, és az uroporfirinogén dekarboxilázt gátolják, amelynek az uroporfirinogén és a karboxilált porfirinek felhalmozódása a következménye. HCV-fertőzöttekben porphyria cutanea tarda korábbi életkorban jelenik meg. Napfényexpozíció után hólyagok, vesiculák alakulnak ki a kézfejeken, illetve az alkarokon. A hypertrichosis, a sclerodermaszerü elváltozások, az alopecia hegképződéssel, a dystrophiás kalcifikáció ulceratióval ritkább eltérések [43].

A Raynaud-szindróma előfordulása 7\% [44].

A necrolyticus acralis erythema, az erythema multiforme kevésbé gyakoriak [13].

\section{Tüdőfibrosis}

Több tanulmány vetette fel a dyspnoe, nem produktív köhögés, szövettanilag interstitialis gyulladás, proliferáló fibroblastgócok, kollagénfibrosis jellemezte pulmonalis fibrosis és az idült HCV-fertőzés kapcsolatát, bár a patogenezis itt sem teljesen tisztázott [13].

\section{Szemészeti megjelenések}

A Sjögren-szindróma okozta xerophthalmia, a cryoglobulinaemiás vasculitis miatti ischaemiás károsodás és a diabeteses retinopathia az idült HCV-fertőzöttekben megjelenő leggyakoribb szemészeti eltérések [45]. Ischaemiás retinopathia interferonkezelés következtében is kialakulhat. Diabeteses betegek érzékenyebbek az interferonkezelés okozta ischaemiás retinopathia kialakulására [45].

A Mooren-fekély fájdalmas, progresszív, kifekélyesedő keratitis, amely a periférián kezdődik, centrális irányban halad. Kialakulásának folyamata nem pontosan ismert, HCV-antigén-keresztreakciót feltételeznek [31].

A HCV-fertőzés összefüggését leírták scleritissel, episcleritissel, trichomegaliával, perifériás ulcerativ keratopathiával, retinopathiával, centrális vénás thrombosissal, maculaoedemával, opticusneuropathiával kapcsolatban is $[13,20]$.

\section{Neuropszichiátriai manifesztációk}

HCV-fertőzöttek 50\%-ában jönnek létre, leggyakoribb a depresszió, az anxietas, a fáradtság vagy az általános 
gyengeség. A betegek 15\%-a rekurrens depressziótól szenved. Hátterében a vírusreplikáció direkt hatása, illetve a kemo- és a citokinek hatása állhat $[46,47]$.

\section{Egyéb}

A hypertrophiás és a dilatatív cardiomyopathia, valamint az idült myocarditis és a krónikus HCV-fertőzés közötti kapcsolat is felmerült. Autoimmun mechanizmust feltételeznek, bár a carotis- és coronariasclerosisban szenvedő egyénekben a HCV-fertőzés gyakoribb [11].

Fizikai aktivitás provokálta fájdalmas végtagok, nagyobb csonttömeggel jellemzett osteosclerosissal (HCAO) összefüggésben is felmerült a $\mathrm{HCV}$ szerepe [48].

\section{Az extrahepaticus manifesztációk kezelése}

Az extrahepaticus szervek érintettségének kezelése részben az antivirális kezelést, részben a B-sejt-depléción keresztül a krioglobulinok képződésének gátlását, valamint az immunszuppresszív kezelést jelenti a szervtámogató kezelések mellett $[17,49,50]$.

\section{LAC-diéta (low-antigen-content diet)}

Minor manifesztációk (purpura, arthralgia, paresthaesia) esetén, a betegség kezdeti szakaszában alkalmazható a LAC-diéta, amely a tojás, a glutén, a tejtermékek, a citrusok, valamint a csokoládé fogyasztásának kerülését jelenti. A nagy antigenitású alimentáris makromolekulákban csökkentett diéta a reticuloendothelialis rendszert segíti a krioglobulinok eltávolításában [11].

\section{Kolchicin}

A gyulladásgátló kolchicin enyhe, középsúlyos kevert cryoglobulinaemiában (1 mg/nap 6-48 hónapig) a klinikai és a laboratóriumi tüneteket javította [51].

\section{Antivirális kezelés}

$\mathrm{Az}$ antivirális kezelés célja a vírus eliminációja, a HCVfertőzésben megjelenő immunkomplexek kialakulásának csökkentése.

Kettős antivirális (IFN + RIBA) kezeléssel a betegek 50-70\%-ánál érhető el javulás az extrahepaticus manifesztációk tekintetében a HCV-RNS-szám csökkenésével. A hosszú távú remisszió 10\%, az antivirális kezelés befejezése után relapsus következhet be. Az interferon számos vasculitises manifesztáció (glomerulonephritis, neuropathia) fellángolását provokálhatja. A ribavirin dózismódosítása szükséges vesemúlködési zavarban [11].

A direkt antivirális kezelések hatékonyabbak, jobban tolerálhatóak és nincs szükség interferon alkalmazására.
Néhány közleményben beszámolnak az újabb direkt antivirális készítmények hatékonyságáról kevert típusú cryoglobulinaemiában, például ombitasvir + paritaprevir + ritonavir + dasabuvir, sofosbuvir + ribavirin, sofosbuvir + simeprevir kezelésekkel kapcsolatban [20].

\section{B-sejt-depléció}

A B-sejt-depléció célja az immunkomplexek és a krioglobulinok képződésének megakadályozása.

A rituximab CD20-ellenes antitest, amely a B-lymphocyták számát csökkenti $\left(375 \mathrm{mg} / \mathrm{m}^{2}\right.$ hetente, négy hétig), a krioglobulinok és a monoklonális IgM képződését mérsékli. Antivirális kezeléssel kombinálva (PEG-IFN- $\alpha-2 b /$ ribavirin) hatékonyabb veseérintettségben, mint az antivirális kezelés önmagában. Biztonságos. Ritkán az IgM-RF-fel komplexet képezve a krioprecipitációt felerősítheti, ezért nagy kiindulási krioglobulinszint esetén plazmacsere után alkalmazható. Cyclophosphamiddal összehasonlítva legalább olyan hatékony, s kevésbé okozza a HCV-fertőzés fellángolását $[11,12]$. A rituximabkezelésre adott válasz körülbelül egy évig tart, majd a cryoglobulinaemiás vasculitis fellángolása következhet be [11].

\section{Nem specifikus immunterápia}

$\mathrm{Az}$ immunszuppresszív kezelés az immunkomplexek szintézisét gátolja a gyulladásos sejtekben, illetve a krioglobulin asszociálta vasculitis kezelését jelenti [12].

A cyclophosphamid (2 $\mathrm{mg} / \mathrm{ttkg} / \mathrm{nap}$ per os) a Blymphocytákat, s így a krioglobulinképződést gátolja. Sajnos, a HCV-fertőzés fellángolását okozhatja [11, 12].

A mycofenolat-mofetil $(2 \times 1 \mathrm{~g} / \mathrm{nap})$ a lymphocytaproliferáció és -funkció effektívebb gátlója. Kevésbé toxikus alternatívája a cryoglobulinaemiás vasculitis remissziójának indukciójára [12]. Antivirális hatása is van, az inozin-monofoszfát-dehidrogenáz enzim (ribavirincélpont) gátlása révén [11].

Súlyos kevert cryoglobulinaemiában nagy dózisú kortikoszteroidok (prednison napi $0,5-1,5 \mathrm{mg} / \mathrm{kg}$ ) vagy intravénás lökésterápia (methylprednisolon $0,5-1,0 \mathrm{~g} /$ nap három napig, majd per os prednison) is alkalmazható. De a vírusreplikációt segítheti, a májbetegséget ronthatja alkalmazásuk [12].

\section{Plazmaferézis}

Akut súlyos manifesztációban a plazmaferézis során történik az immunkomplexek, krioglobulinok eltávolítása a plazmából. Főleg rapid progresszív glomerulonephritisben effektív. Immunszuppresszív kezeléssel kombinálandó, hogy az immunkomplexek és krioglobulinok újraképződését és felhalmozódását megelőzhessük [12]. 


\section{Hematológia}

Lymphoproliferatív betegségek - NHL

Immunthrombocytopeniás purpura

MALT-lymphoma

MGUS

\section{Neurológia}

Perifériás neuropathia

Ischaemiás stroke

Lacunaris szindróma

Kognitív károsodás

Encephalopathia

\section{Szemészet}

Sjögren-szindróma

Mooren-fekély

Scleritis

Episcleritis

Trichomegalia

Perifériás ulceratív keratopathia

Retinopathia maculaoedemával

Opticusneuropathia

\author{
Bőrgyógyászat \\ Cutan vasculitis \\ Raynaud-szindróma \\ Livedo reticularis \\ Urticaria \\ Pruritus \\ Lichen planus \\ Psoriasis \\ Erythema nodosum \\ Erythema multiforme \\ Porphyria cutanea tarda \\ Necrolyticus acralis erythema
}

\section{Reumatológia}

Polyarthritis-reumaszerü arthritis

Mono-oligoarthritis

Arthraigia

Myalgia

Diabetológia

2-es típusú diabetes mellitus

Pszichiátria

Depresszió

Anxietas

Fáradtság

\section{Nefrológia}

Membranoproliferatív glomerulonephritis

Membranosus nephropathia

Fokális szegmentális glomerulonephritis

Postinfectiosus glomerulonephritis

Fibrillaris glomerulonephritis

IgA-nephropathia (Berger-betegség)

Renalis thromboticus microangiopathia

Interstitialis nephritis

Pulmonológia

Tüdőfibrosis

\section{Endokrinológia}

Hashimoto-thyreoiditis

\section{Kardiológia}

Hypertrophiás és dilatatív cardiomyopathia Myocarditis

\section{HCV-asszociált lymphoproliferativ betegségek kezelése}

A low-grade HCV-pozitív NHL-ben a szövettani szubtípustól függetlenül antivirális kezelés alkalmazandó. Közepes és high-grade NHL-ben kemoterápia, majd antivirális kezelés is szükséges mint fenntartó kezelés. A kemoterápia a viraemia rosszabbodásához vezethet, ezért a kezelés alatt a vírusszintet monitorozni kell. A transzamináz-aktivitások rendszeres ellenőrzése is szükséges, mert a HCV-pozitív betegek érzékenyebbek a kemoterapeutikumok okozta májkárosításra [11].

\section{A jövő terápiás lehetőségei}

Kis dózisú IL-2 a HCV-asszociált kevert cryoglobulinaemiás vasculitis alternatívája lehet [52]. A regulátor T-sejtek (Treg) túlélését és múködését segíti, gyulladást és oxidatív stresszt csökkentő hatása is van [12].

\section{Következtetések}

A hepatitis C-vírus az idült májbetegségek egyik leggyakoribb oka. A HCV-fertőzöttek több mint 50\%-ában jelenhet meg extrahepaticus érintettség, amelynek megjelenése előre nem megjósolható és a májbetegség stádiumától függetlenül alakul ki. Gyengeség, fáradtság a leggyakoribb tünetek, de a vírusfertőzés lényegében bármely szervrendszert érinthet. Cryoglobulinaemia, a vírus direkt hatása, illetve immunfolyamatok révén az extrahepaticus szervek érintettsége jöhet létre, amely a
HCV-fertőzöttek életminőségét rontja, a morbiditást, mortalitást növeli. A legsúlyosabb manifesztációk a cryoglobulinaemia okozta vese- és perifériás idegrendszeri érintettség. Számos autoimmun betegség is megjelenhet (Hashimoto-thyreoiditis, ITP, Sjögren-szindróma) (1. ábra). A genetikai tényezók hajlamosító szerepe további vizsgálatokat igényel.

Kezelésüket részben a vírusreplikáció gátlása antivirális kezelés révén, részben a B-sejt-csökkentő, részben az immunszuppresszív kezelés jelenti.

$\mathrm{Az}$ antivirális kezelés a vírusreplikáció gátlása révén a krioglobulinképződést csökkenti, de más extrahepaticus tüneteket ronthatnak (például interferonkezelés). Az interferonmentes kezelések újabb lehetőséget jelenthetnek. Az extrahepaticus manifesztációkat a betegek kezelési prioritásánál figyelembe kell venni, hiszen a víruseradikáció a májon kívüli szervi érintettséget is gyógyítja és a HCV-fertőzéssel összefüggő szisztémás betegségek megjelenését, e betegségek okozta halálozást csökkenti.

Anyagi támogatás: A közlemény megírása anyagi támogatásban nem részesült.

Szerzôi munkamegosztás: H. K.: Téma felvetése. Irodalomkutatás. A közlemény megírása. E. A.: Irodalomkutatás, közlemény megírása. L. G.: A cikkírás felügyelete. A cikk végleges változatát valamennyi szerző elolvasta és jóváhagyta.

Érdekeltségek: A szerzőknek nincsenek érdekeltségeik. 


\section{Irodalom}

[1] Wong, J. B.: Hepatitis C: cost of illness and considerations for the economic evaluation of antiviral therapies. Pharmacoeconomics, 2006, 24(7), 661-672.

[2] Perz, J. F., Armstrong, G. L., Farrington, L. A., et al.: The contributions of hepatitis $\mathrm{B}$ virus and hepatitis $\mathrm{C}$ virus infections to cirrhosis and primary liver cancer worldwide. J. Hepatol., 2006, 45(4), 529-538.

[3] Alter, M. J.: Epidemiology of hepatitis C virus infection. World J. Gastroenterol., 2007, 13(17), 2436-2441.

[4] Ali, A., Zein, N. N.: Hepatitis C infection: a systemic disease with extrahepatic manifestations. Cleve. Clin. J. Med., 2005, 72(11), 1005-1019.

[5] Pascual, M., Perrin, L., Giostra, E., et al.: Hepatitis C virus in patients with cryoglobulinemia type II. J. Infect. Dis., 1990, 162(2), 569-570.

[6] Galossi, A., Guarisco, R., Bellis, L., et al.: Extrahepatic manifestations of chronic HCV infection. J. Gastrointestin. Liver Dis., 2007, 16(1), 65-73.

[7] Zignego, A. L., Brechot, C.: Extrahepatic manifestations of HCV infection: facts and controversies. J. Hepatol., 1999, 31(2), 369376.

[8] Tampaki, M., Koskinas, J.: Extrahepatic immune related manifestations in chronic hepatitis C virus infection. World J. Gastroenterol., 2014, 20(35), 12372-12380.

[9] Yang, D. H., Ho, L. J., Lai, J. H.: Useful biomarkers for assessment of hepatitis $\mathrm{C}$ virus infection-associated autoimmune disorders. World J. Gastroenterol., 2014, 20(11), 2962-2970.

[10] Younossi, Z., Park, H., Henry, L., et al.: Extrahepatic manifestations of hepatitis C: A meta-analysis of prevalence, quality of life, and economic burden. Gastroenterology, 2016, 150(7), 15991608.

[11] Khattab, M. A., Eslam, M., Alavian, S. M.: Hepatitis C virus as a multifaceted disease: a simple and updated approach for extrahepatic manifestations of hepatitis $\mathrm{C}$ virus infection. Hepat. Mon., $2010,10(4), 258-269$

[12] Ozkok, A., Yildiz, A.: Hepatitis C virus associated glomerulopathies. World J. Gastroenterol., 2014, 20(24), 7544-7554.

[13] Gill, K., Ghazinian, H., Manch, R., et al.: Hepatitis C virus as a systemic disease: reaching beyond the liver. Hepatol. Int., 2016, $10(3), 415-423$.

[14] Ferri, C.: Mixed cryoglobulinemia. Orphanet J. Rare Dis., 2008 , 3,25 .

[15] Ferri, C., Greco, F., Longombardo, G., et al.: Antibodies to hepatitis $\mathrm{C}$ virus in patients with mixed cryoglobulinemia. Arthritis Rheum., 1991, 34(12), 1606-1610.

[16] Sene, D., Ghillani-Dalbin, P., Thibault, V., et al.: Longterm course of mixed cryoglobulinemia in patients infected with hepatitis C virus. J. Rheumatol., 2004, 31(11), 2199-2206.

[17] Ragab, G., Hussein, M. A.: Vasculitic syndromes in hepatitis C virus: A review. J. Adv. Res., 2017, 8(2), 99-111.

[18] Sautto, G., Mancini, N., Clementi, M., et al.: Molecular signatures of hepatitis $\mathrm{C}$ virus (HCV)-induced type II mixed cryoglobulinemia (MCII). Viruses, 2012, 4(11), 2924-2944.

[19] Cohen, S. J., Pittelkow, M. R., Su, W. P.: Cutaneous manifestations of cryoglobulinemia: clinical and histopathologic study of seventy-two patients. J. Am. Acad. Dermatol., 1991, 25(1), 21-27.

[20] Tang, L., Marcell, L., Kottilil, S.: Systemic manifestations of hepatitis C infection. Infect. Agent. Cancer, 2016, 11, 29. doi 10.1186/s13027-016-0076-7

[21] Misiani, R., Bellavita, P., Fenili, D., et al.: Hepatitis C virus infection in patients with essential mixed cryoglobulinemia. Ann. Intern. Med., 1992, 117(7), 573-577.

[22] Younis, L. K., Talaat, F. M., Deif, A. H., et al.: Immunohistochemical detection of HCV in nerves and muscles of patients with $\mathrm{HCV}$ associated peripheral neuropathy and myositis. Int. J. Health Sci. (Qassim), 2007, 1(2), 195-202.
[23] Gemignani, F., Brindani, F., Alfieri, S., et al.: Clinical spectrum of cryoglobulinaemic neuropathy. J. Neurol. Neurosurg. Psychiatry, 2005, 76(10), 1410-1414.

[24] Casato, M., Saadoun, D., Marchetti, A., et al.: Central nervous system involvement in hepatitis $\mathrm{C}$ virus cryoglobulinemia vasculitis: a multicenter case-control study using magnetic resonance imaging and neuropsychological tests. J. Rheumatol., 2005, 32(3), 484-488.

[25] Palazzi, C., D'Angelo, S., Olivieri, I.: Hepatitis C virus-related arthritis. Autoimmun. Rev., 2008, 8(1), 48-51.

[26] Kemmer, N. M., Sherman, K. E.: Hepatitis C-related arthropathy: Diagnostic and treatment considerations. J. Musculoskelet. Med., 2010, 27(9), 351-354.

[27] McGuire, B. M., Julian, B. A., Bynon, J. S. Jr., et al.: Brief communication: Glomerulonephritis in patients with hepatitis $\mathrm{C}$ cirrhosis undergoing liver transplantation. Ann. Intern. Med., 2006, 144(10), 735-741.

[28] Aref, S., Sleem, T., El Menshawy, N., et al.: Antiplatelet antibodies contribute to thrombocytopenia associated with chronic hepatitis C virus infection. Hematology, 2009, 14(5), 277-281.

[29] Lakatos, M., Hagymási, K., Lengyel G.: Fatty liver and hepatitis C virus infection. [A májzsírosodás és a hepatitis C-vírus-fertőzés.] Orv. Hetil., 2011, 152(38), 1513-1519. [Hungarian]

[30] Adinolfi, L. E., Rinaldi, L., Guerrera, B., et al.: NAFLD and $\mathrm{NASH}$ in HCV infection: Prevalence and significance in hepatic and extrahepatic manifestations. Int. J. Mol. Sci., 2016, 17(6), 803. doi: $10.3390 /$ ijms 17060803

[31] Cheng, Z., Zhou, B., Shi, X., et al.: Extrahepatic manifestations of chronic hepatitis C virus infection: 297 cases from a tertiary medical center in Beijing, China. Chin. Med. J. (Engl.), 2014, 127(7), 1206-1210.

[32] Narita, R., Abe, S., Kibara, $\Upsilon$., et al.: Insulin resistance and insulin secretion in chronic hepatitis $\mathrm{C}$ virus infection. J. Hepatol., 2004, 41(1), 132-138.

[33] Lonardo, A., Adinolfi, L. E., Petta, S., et al.: Hepatitis C and diabetes: the inevitable coincidence? Expert Rev. Anti Infect. Ther., 2009, 7(3), 293-308.

[34] Gastaldi, G., Goossens, N., Clément, S., et al.: Current level of evidence on causal association between hepatitis $C$ virus and type 2 diabetes: A review. J. Adv. Res., 2017, 8(2), 149-159.

[35] Akeno, N., Blackard, J. T., Tomer, Y.: HCV E2 protein binds directly to thyroid cells and induces IL- 8 production: a new mechanism for HCV induced thyroid autoimmunity. J. Autoimmun., 2008, 31(4), 339-344.

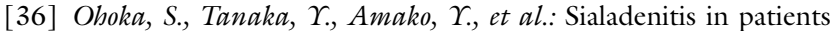
with chronic hepatitis $\mathrm{C}$ is not directly related to hepatitis $\mathrm{C}$ virus. Hepatol. Res., 2003, 27(1), 23-29.

[37] Himoto, T., Masaki, T.: Extrahepatic manifestations and autoantibodies in patients with hepatitis C virus infection. Clin. Dev. Immunol., 2012, 2012, 871401.

[38] Antonelli, A., Ferri, C., Fallahi, P.: Thyroid cancer in patients with hepatitis C infection. JAMA, 1999, 281(17), 1588

[39] Blackard, J. T., Kong, L., Huber, A. K., et al.: Hepatitis C virus infection of a thyroid cell line: implications for pathogenesis of hepatitis C virus and thyroiditis. Thyroid, 2013, 23(7), 863870.

[40] Voulgaris, T., Sevastianos, V. A.: Atherosclerosis as extrahepatic manifestation of chronic infection with hepatitis $\mathrm{C}$ virus. Hepat. Res. Treat., 2016, 2016, 7629318.

[41] Wong, R. J., Kanwal, F., Younossi, Z. M., et al.: Hepatitis C virus infection and coronary artery disease risk: a systematic review of the literature. Dig. Dis. Sci., 2014, 59(7), 1586-1593.

[42] Boddi, M., Abbate, R., Chellini, B., et al.: HCV infection facilitates asymptomatic carotid atherosclerosis: preliminary report of HCV RNA localization in human carotid plaques. Dig. Liver Dis., 2007, 39(Suppl. 1), S55-S60. 
[43] Quansah, R., Cooper, C. J., Said, S., et al.: Hepatitis C- and HIVinduced porphyria cutanea tarda. Am. J. Case Rep., 2014, 15, $35-40$.

[44] Cacoub, P., Poynard, T., Ghillani, P., et al., for the MULTIVIRC GROUP: Extrahepatic manifestations of chronic hepatitis C. Arthritis Rheum., 1999, 42(10), 2204-2212.

[45] Zegans, M. E., Anninger, W., Chapman, C., et al.: Ocular manifestations of hepatitis $\mathrm{C}$ virus infection. Curr. Opin. Ophthalmol., 2002, 13(6), 423-427.

[46] Fletcher, N. F., McKeating, J. A.: Hepatitis C virus and the brain. J. Viral Hepatol., 2012, 19(5), 301-306.

[47] Yarlott, L., Heald, E., Forton, D.: Hepatitis C virus infection, and neurological and psychiatric disorders - A review. J. Adv. Res., $2017,8(2), 139-148$

[48] Khosla, S., Hassoun, A. A., Baker, B. K., et al.: Insulin-like growth factor system abnormalities in hepatitis C-associated osteosclerosis. Potential insights into increasing bone mass in adults. J. Clin. Invest., 1998, 101(10), 2165-2173.

[49] Rosenthal, E., Cacoub, P.: Extrahepatic manifestations in chronic hepatitis C virus carriers. Lupus, 2015, 24(4-5), 469-482.
[50] Ramos-Casals, M., Zignego, A. L., Ferri, C., et al., on behalf of the International Study Group of Extrahepatic Manifestations related to $H C V$ (ISG-EHCV): Evidence-based recommendations on the management of extrahepatic manifestations of chronic hepatitis C virus infection. J. Hepatol., 2017 Feb 27. doi: http://dx.doi. org/10.1016/j.jhep.2017.02.010 [Epub ahead of print]

[51] Monti, G., Saccardo, F., Rinaldi, G., et al.: Colchicine in the treatment of mixed cryoglobulinemia. Clin. Exp. Rheumatol., 1995, 13(Suppl. 13), S197-S199.

[52] Saadoun, D., Rosenzwajg, M., Joly, F., et al.: Regulatory T-cell responses to low-dose interleukin-2 in $\mathrm{HCV}$-induced vasculitis. N. Engl. J. Med., 2011, 365(22), 2067-2077.

(Hagymási Krisztina dr., Budapest, Szentkirályi u. 46., 1088 e-mail: hagymasi.krisztina@med.semmelweis-univ.hu)
A Markusovszky Lajos Alapítvány Kuratóriuma és az Akadémiai Kiadó meghívja Önt

az Orvosi Hetilap Szerkesztőbizottságának és Szerkesztőségének hagyományos évi Markusovszky Lajos-emlékülésére.

Időpont: 2017. május 11. (csütörtök) 10:30

Helyszín: az Aesculap Akadémia konferenciaterme (Budapest XI., Halmi u. 20-22. - Tétényi út 12-16. sarok)

Az ünnepségre szeretettel várjuk!
Program:

Az Orvosi Hetilap - Markusovszky Lajos Alapítvány és a Dr. Fehér János Emlékére Alapítvány 2017. évi kitüntetéseinek ünnepélyes átadása

- "Orvosi Hetilap Markusovszky Lajos-emlékérem"

- "Orvosi Hetilap Markusovszky Lajos-dijak"

- Referensek munkájának elismerése

- „Dr. Fehér János Emlékére Alapítvány-dij” átadása

\section{Markusovszky Lajos-emlékelőadás}

Fogadás

Kérjük, jelezze részvételi szándékát Budai Editnél az edit.budai@akademiai.hu e-mail címen. 